\title{
George L. Mosse Memorial Symposium
}

Introduction

\section{Phyllis Cohen Albert and Alex Sagan}

Minda de Gunzburg Center for European Studies, Harvard University

George L. Mosse died on January 22, 1999, leaving a legacy of scholarly innovation in the study of European, German, and GermanJewish history. The memorial symposium of October 1, 1999 that produced the following articles brought together some of the many students, colleagues, and friends who were deeply influenced by Mosse's life and work. They offered reflections on his contributions as researcher, author, teacher, and friend.

Born in Berlin in 1918, Mosse fled Nazi Germany for England in 1933, where he attended secondary school and began his university studies at Cambridge. He came to the United States, graduated from Haverford College in Pennsylvania, and in 1946 received his doctorate in history from Harvard. After a decade of teaching at the University of Iowa, he joined the faculty of the University of WisconsinMadison in 1955, where he lectured on European intellectual and cultural history and modern Jewish history until his retirement in 1988. From 1960 he also served as visiting professor at the Hebrew University of Jerusalem.

Mosse began as a historian of the Reformation and the broad sweep of European cultural history, but he is best remembered for his studies of the nineteenth and twentieth centuries. His work on the origins of Nazism departed from traditional political explanations, reconstructing the cultural roots of Völkish nationalism. The innovative questions Mosse asked, including the role of myth, stereotype, and symbol, opened up new approaches to the study of mass politics, 
fascism, racism, Jewish history, sexuality, and personal identity. His publications, various editions, and translations number more than three hundred.

In 1980 Mosse was the inaugural speaker for the Study Group on the Jews in Modern Europe, a public seminar at Harvard University's Center for European Studies. As the study group's current chairs, we therefore decided to remember Mosse and his connection to our work by organizing what became the first of several symposia held around the world in his memory. ${ }^{1}$

While no claim was made to cover the entire range of Mosse's contributions, the speakers succeeded in assessing major aspects of his legacy. In the papers that follow, Paul Breines probes "George's voice" in both its written and spoken form, while exploring his critique of middle-class respectability. Jeffrey Herf shows how Mosse "recast" cultural and intellectual history through innovative studies of Nazism, fascism and European racism. With reference to Mosse's own autobiographical reflections, Anson Rabinbach offers a broad assessment of the place of antifascism in political and intellectual history. Steven E. Aschheim stresses Mosse's refusal to "ghettoize" Jewish history by using it, instead, to illuminate general developments in European society. The comprehensive bibliography of Mosse's works that follows these conference papers was prepared subsequently by John Tortorice for publication here.

\section{Note}

1. Other groups joined us in cosponsoring the event: Harvard's departments of History and Germanic Languages and Literatures, and the Center for European Studies' study groups on Germany, Culture and Politics in Central Europe, and "After the Fall." 